возможным спрогнозировать температуру обработки. Получение красителя из подсушенных образцов позволит уменьшить содержание сорных включений.

$$
\text { *** }
$$

1. Бриттон Г. Биохимия природных пигментов:пер.с англ.-М.: Мир,-1986. 422 c.

2. Betalains in the era of global agri-food science, technology and nutritional health / D.A. Moreno [et al.]// J. Phytochem. - 2008. - P. 261-280.

3. Саенко И.И., Тарасенко О.В., Дайнеко В.И., Дайнеко Л.А. Бетацианины корнеплодов свеклы столовой// Научные ведомости Белгорородского государственного университета. Серия естественные науки. № 3(122).-2012. С.194-200.

\title{
Ерзаева А.С. \\ Разработка технологической карты урока по теме «Получение металлов»
}

Самарский государственный социально-педагогический университет (Россия, Самара)

doi: $10.18411 / \mathrm{lj}-02-2021-39$

idsp: ljournal-02-2021-39

Научный руководитель

Сафина Л.Г.

\section{Аннотация}

Разработана технологическая карта урока по теме «Получение металлов». Разработанный урок - практикум, способствует не только изучению данной темы, но и развитию заинтересованности учащихся в школьном предмете химия. Является одной из форм организации образовательного процесса и направлен на получение практических навыков на основе теории.

Ключевые слова: технологическая карта, урок, металл.

\section{Abstract}

A technological map of the lesson on the topic "Obtaining metals"has been developed. The developed practical lesson contributes not only to the study of this topic, but also to the development of students ' interest in the school subject of chemistry. It is one of the forms of organization of the educational process and is aimed at obtaining practical skills based on theory.

Keywords: technological map, lesson, metal.

Важнейшая задача современной школы - органическое сочетание обучения, воспитания и развития. Химия как учебный предмет средней школы вносит существенный вклад в ее решение. Ведущее место в преподавании химии занимает школьный химический эксперимент. Это основной и специфический метод обучения, который непосредственно знакомит с химическими явлениями и одновременно развивает познавательную деятельность учащихся.

В школьном курсе химии, по программе предметной линии учебников О.С. Габрилян. 8-9 классы. - М: Просвещение, 2017; выделено временя на изучение металлов, поэтому считаем, что целесообразно знакомить обучающихся с данным типом веществ во время урока. Нами была разработана технологическая карта урока по теме «Получение металлов». Разработанный урок - практикум, способствует не только изучению данной темы, но и развитию заинтересованности учащихся в школьном предмете химия.

Урок-практикум является одной из форм организации образовательного процесса и направлен на получение практических навыков на основе теории. У учеников улучшаются коммуникационные способности, так как дети работают в группах.

Цель занятия - познакомить учащихся с металлами. 
В таблице 1 представим подробный ход занятия.

Фрагмент технологической карты урока

Таблица 1.

\begin{tabular}{|c|c|c|c|c|c|}
\hline \multicolumn{3}{|c|}{ Организация деятельности по достижению образовательных результатов } \\
\hline \multirow{2}{*}{ Деятельность учителя } & \multirow{2}{*}{$\begin{array}{c}\text { Деятельность } \\
\text { учащихся }\end{array}$} & \multicolumn{3}{|c|}{ Формируемы } \\
\cline { 3 - 6 } & П УУ & Р & К & Л \\
\hline 1 & 2 & 3 & 4 & 6 \\
\hline
\end{tabular}

I. Вводная часть: организационный момент, актуализация и мотивация учебной деятельности, целеполагание (10 минут)

1. Организует учащихся, приветствует их, проверяет присутствующцих (2 мин.):

настраивает обучающихся на учебную активность; зрительно пров одит проверку готовность класса к уроку; приветствует обучающихся; подмечает отсутствующих

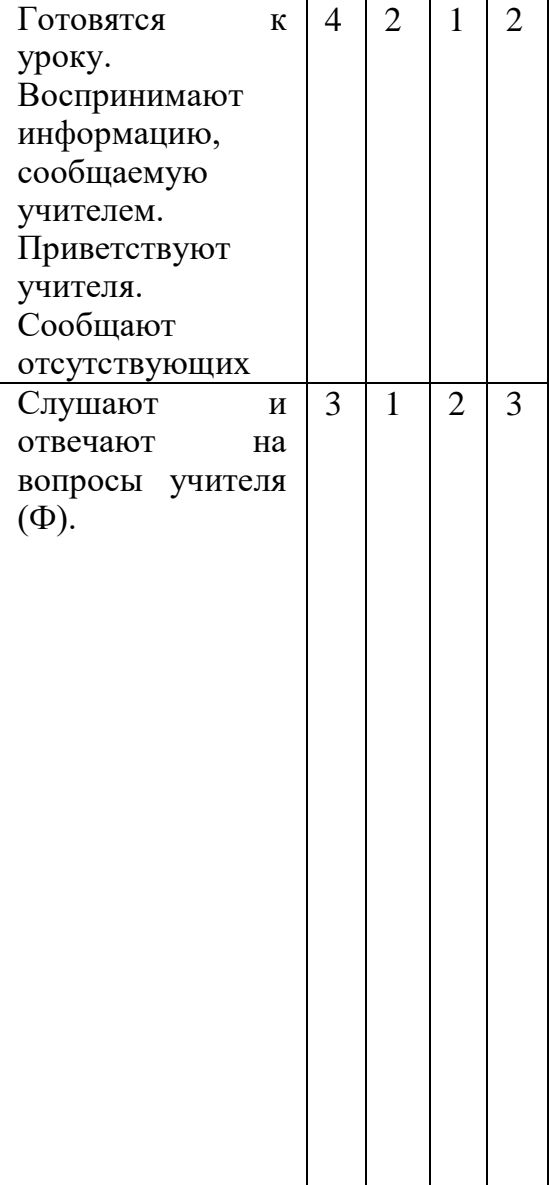
уроку. учителем. Приветствуют учителя. Сообщают отсутствующих

\section{3. Дает целевую установку (1-2 мин.):} дает ответить на вопрос:

- Какая задача нашего урока?

Редактирует, также озвучивает задачу урока вопросы учителя

В природе ничего другого нет

Ни здесь, ни там, в космических глубинах,

Bce: от писчинок малых до планет -

Из элементов состоит единых

Как формула, как график трудовой

Строй менделеевской системы строгий.

Вокруг тебя творится мир живой,

Входи в него, вдыхай, руками трогай!

Ты знаешь газ легчайший - водород,

В соединеньи с кислородом - это

Июньский дождь от всех своих щедрот,

Сентябрьские туманы на рассветах.

Кипит железо, серебро, сурьма

И темно-бурые растворы брома,

И кажется вселенная сама

Одной лабораторией огромной.

II. Основная часть: изучение нового материала, закрепление, первичный контроль и коррекция (25 минут)

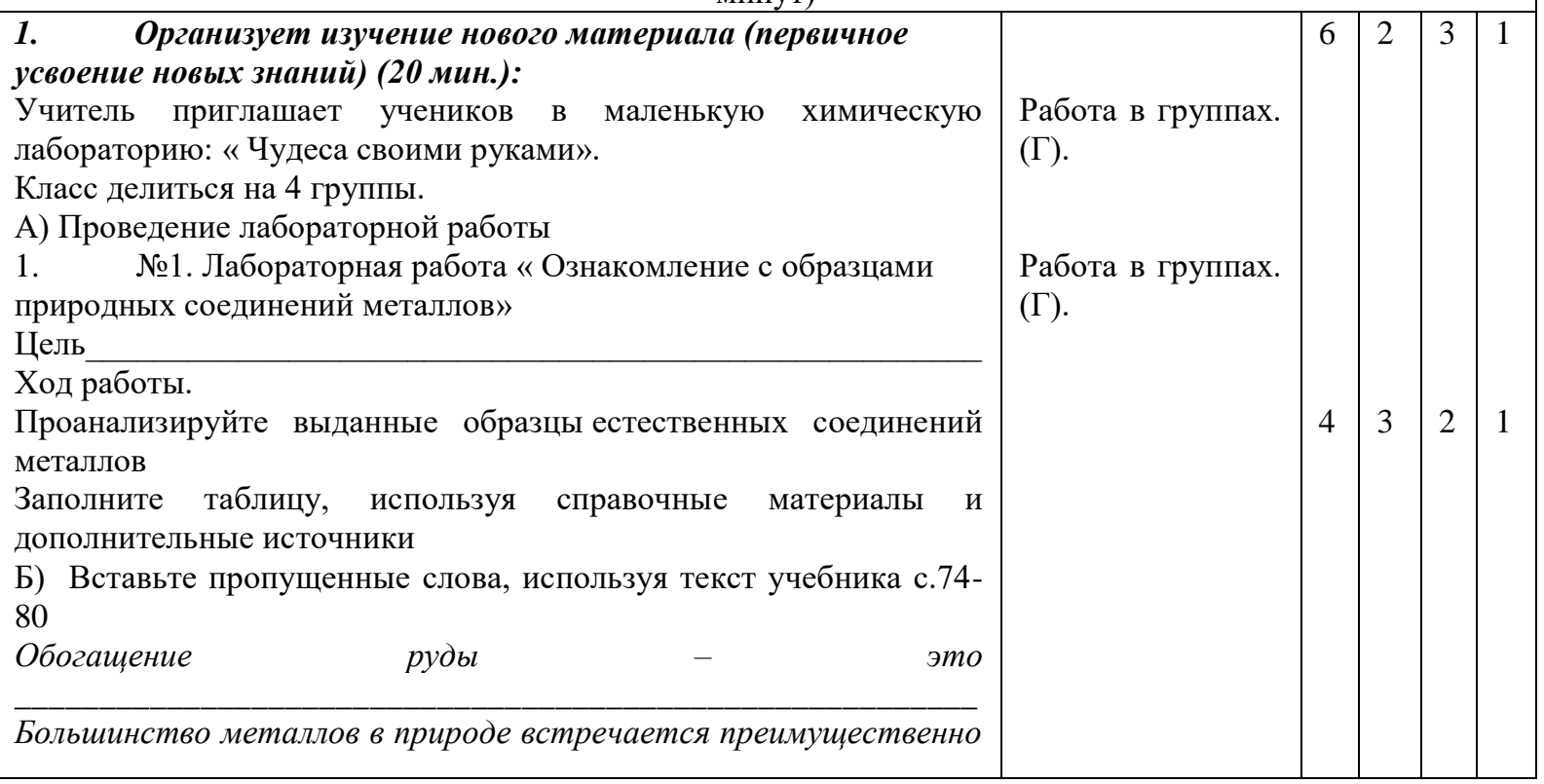




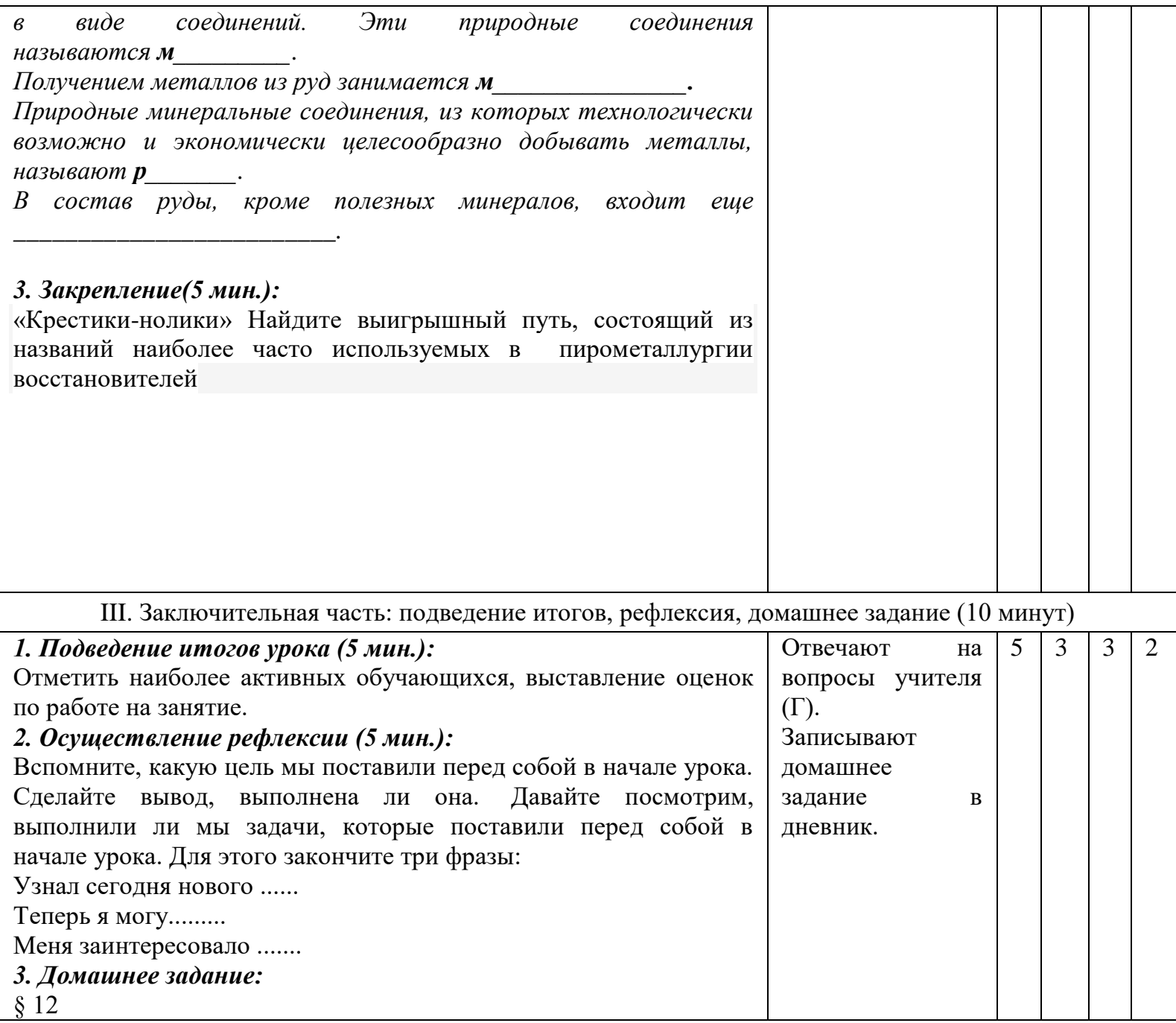
Химии.

Разработанная нами технологическая карта может быть использована на уроках

Только лишь введение обучающихся в интенсивную экспериментальную познавательную работа дает им вероятность проникнуть в сущность химического явления, освоить его на уровне общих закономерностей курса химии, использовать усвоенный материал в качестве способа дальнейшего познания. Процесс развивающего обучения с использованием эксперимента порождает внутренние стимулы учения, способствует переходу знаний в убеждения, развитию познавательной самостоятельности в деятельности учащихся. Таким образом, все это вносит существенный вклад в формирование у учащихся основ научного мировоззрения.

$$
* * *
$$

1. Аршанский Е.Я. Методика обучения химии в классах гуманитарного профиля. - Москва: Гостехиздат, 2006. - 897 с.

2. Аршанский, Е. Я. Методика обучения химии в классах гуманитарного профиля / Е.Я. Аршанский. - М.: Вентана-Граф, 2006. - 176 с.

3. Дьякович, С.В. Профориентация учащихся при обучении химии / С.В. Дьякович, Р.Н. Князева. М.Просвещение, 1982

4. Зайцев, О. С. Методика обучения химии / О.С. Зайцев. - М.: Владос, 2011. - 384 с.

5. Кирюшкин, Д. М. Методика преподавания химии / Д.М. Кирюшкин. - М.: Государственное учебно-педагогическое издательство Министерства просвещения РСФСР, 2001. - 352 с.

6. Качалова, Г. С. Формирование базисной компетентности учащихся по неорганической химии: монография / Г. С. Качалова. - Новосибирск: Изд. НГПУ, 2011. - 153 с.

7. Чернобельская, Г. М. Методика обучения химии в средней школе / Г.М. Чернобельская. - М.: Владос, 2000. - 336 с. 